\title{
Behind the Text of the Basic Law: Some Constitutional Fundamentals
}

\author{
Prof Johannes M M Chan \\ Faculty of Law \\ The University of Hong Kong
}

Every constitution is shaped by its unique history and the social and political circumstances of the country in which it operates. Our understanding and interpretation of the constitution cannot be divorced from the social, political and historical contexts of the jurisdiction in which the constitution is to operate. At the same time, constitutions, by their very nature, can only contain general principles. While they prescribe a general framework for assessing the constitutionality of executive acts and, in some jurisdictions, statutory provisions, a literal reading of the constitutional text in most cases does not provide an obvious answer to many constitutional issues before the courts. By interpreting the constitution, the courts give life to the constitution. Yet interpretation is rarely a neutral process. In giving meaning to the general text of a constitution, the courts may from time to time rely on various fundamental values in our constitutional system. Such fundamental values may not be readily visible from the text of the constitution. Professor Lawrence Tribe, in his inspiring work, described these values as "The Invisible Constitution". ${ }^{1}$ This may be putting the case too high, for a constitution, visible or otherwise, suggests a coherent and structured system of values and principles. It may be difficult to find such a coherent pattern for a young constitution such as the Basic Law in Hong Kong that is less than 25 years old. Instead, this paper argues that some fundamental values, which I would call Constitutional Fundamentals, do exist behind the text. These principles are interstitial, vague, and far from being coherent or structured, and may sometimes even be in conflict with one another. Nonetheless, they exist, guide and influence the development of the constitution. It is not the purpose of this paper to argue whether these principles are desirable or not, but simply to contend that they exist and are discernible, and this paper tries to identify some of these constitutional fundamentals that underline the Basic Law of Hong Kong.

\section{The Social, Political and Historical Contexts of the Basic Law}

Hong Kong was partially ceded and partially leased to Britain in the $19^{\text {th }}$ century under three different treaties. The common law system was transplanted to Hong Kong that was since governed by a relatively benign colonial regime.

\footnotetext{
* I am grateful to my colleague Ms Cora Chan for her insightful comments on an earlier draft of this article. Any mistake remains, of course, my sole responsibility.

${ }^{1}$ Lawrence Tribe, The Invisible Constitution (Oxford University Press, 2008).
} 
Traditionally it was a place of refuge for those who wanted to avoid civil unrest in Mainland China. The population soared soon after the Second World War, and it remains today that about half of the population are migrants or refugees from the Mainland. By the 1980s, Hong Kong has developed into one of the major financial centres in the world, with a GDP comparable to many developed countries and enjoying a high degree of freedom and liberty. In contrast, China at that time had just emerged from the ten-year long Cultural Revolution, during which there were widespread persecutions and massive destruction of anything representing the establishment or considered to be non-conforming with the prevailing political ideology. All universities were closed down during the Cultural Revolution. By the end of the Cultural Revolution in 1976, the country was almost at the brink of bankruptcy and a stage of lawlessness. Since 1978, the country embarked on a massive rebuilding process with very noticeable success. In 1984, the Sino-British Joint Declaration was concluded under which China would resume sovereignty over Hong Kong under the principle of "One Country, Two Systems". Hong Kong would retain "a high degree of autonomy", and would preserve its own legal, social and economic systems. Mainland law and policies would not apply to Hong Kong, and fundamental rights would be guaranteed. These promises were given effect by the Basic Law, which serves as the constitution of Hong Kong. The Basic Law was promulgated by the National People's Congress of the People's Republic of China ("PRC") in April 1990. On 1 July 1997, Hong Kong became a Special Administrative Region of the PRC ("HKSAR").

It is not surprising that many people in Hong Kong did not feel confident about the future master, especially when half of the population were once refugees fleeing the Mainland and Communist rule. Many provisions in the Basic Law were hence drafted with the Mainland system in mind, such as the right to freedom of choice of occupation, ${ }^{2}$ the freedom to engage in academic, literary and artistic creation, ${ }^{3}$ a right to judicial remedies, ${ }^{4}$ and the right to freely raise a family. ${ }^{5}$ Thus, there are two constant themes in the interpretation of the Basic Law, namely the preservation of the integrity of the common law system, including the enjoyment of liberty and freedom under the common law system, and the maintenance and continuity with the previous system.

\section{The Constitutional Context of the Basic Law}

Chapter 3 of the Basic Law provides for the protection of fundamental rights and freedoms of Hong Kong Inhabitants. Article 39 of the Basic Law provides that the provisions of the International Covenant on Civil and Political Rights ("ICCPR") and the International Covenant on Economic, Social and Cultural Rights ("ICESCR") shall remain in force and shall be implemented through the

\footnotetext{
2 Art 33, Basic Law.

${ }^{3}$ Art 34. Intellectuals were severely suppressed and widely persecuted for their writings during the Cultural Revolution.

4 Art 35.

${ }^{5}$ Art 37. The one-child policy in the PRC was lifted only in 2015.
} 
laws of the HKSAR. The ICCPR, but not the ICESCR, was incorporated into the domestic law of the HKSAR by the Hong Kong Bill of Rights Ordinance, which reproduced the substantive rights provisions of the ICCPR. ${ }^{6}$ The PRC has ratified the ICESCR, but not the ICCPR. Article 39 further provides that any restriction of the rights and freedoms enjoyed by Hong Kong residents shall be prescribed by law and shall not contravene the ICCPR and the ICESCR as applied to Hong Kong.

Soon after the Basic Law came into effect, the Hong Kong Court of Final Appeal has, in a series of cases, laid down the general approach to the interpretation of the Basic Law. The courts must be vigilant in the protection of fundamental rights and should adopt a generous and purposive interpretation so as to give full measures to individual rights. A literal, technical, narrow or rigid approach should be avoided. ${ }^{7}$ Any restriction on a fundamental right must be narrowly interpreted and rigorously examined. Such restriction, in order to pass muster the constitutional requirements, must be prescribed by law and satisfy the tests of rationality and proportionality. The burden of justification of any restriction rests on the Government. 8

The Court of Final Appeal noted that a purposive approach to interpretation is necessary "because a constitution states general principles and expresses purposes without condescending to particularity and definition of terms." 9 Hence, "gap and ambiguities are bound to arise and, in resolving them, the courts are bound to give effect to the principles and purposes declared in, and to be ascertained from, the constitution and relevant extrinsic materials." 10 Not only must the courts consider the purpose of the instrument, but that it must also interpret the language of its text in the light of the context, "context being of particular importance in the interpretation of a constitutional instrument."11 In this regard, it is interesting to note the observation of Sir Anthony Mason, a nonpermanent judge of the Court of Final Appeal, made in an extra-judicial lecture, that "the lack of a fully democratic universal franchise and the relationship created by the Basic Law between a strong executive government and a weak legislature might suggest that the community and the media may place greater

${ }^{6}$ The substantive rights provisions of the ICCPR, with the exception of the right of a child to a nationality and a replacement of "every citizen" by "every permanent resident" regarding the right to vote and to stand for election, were reproduced in Part II of the Bill of Rights Ordinance. Part II is known as the Bill of Rights. Reservations to the ICCPR that were entered into by the UK upon ratification of the ICCPR were reproduced in Part III of the Bill of Rights Ordinance.

${ }^{7} \mathrm{Ng}$ Ka Ling v Director of Immigration (1999) 2 HKCFAR 4, pars 30.

${ }^{8} \mathrm{Ng}$ Ka Ling v Director of Immigration (1999) 2 HKCFAR 4, paras 28-30; Leung Kwok Hung v HKSAR (2005) 8 HKCFAR 229, para 116; Yeung May Wan v HKSAR (2005) 8 HKCFAR 137, paras 1-3.

${ }^{9} \mathrm{Ng}$ Ka Ling v Director of Immigration (1999) 2 HKCFAR 4, para 28, per Li CJ. 10 Ibid.

11 Ibid. For extrinsic materials, Li CJ specifically referred to the Joint Declaration. 
expectations in the curial protection of individual rights and due process than is the case in other jurisdictions." 12

In construing the Basic Law, the Hong Kong courts have been receptive to a wide range of international and comparative materials. ${ }^{13}$ This is partly due to the international origin of the Hong Kong Bill of Rights, which is a replica of the ICCPR, and partly to the practice of having an overseas judge in every substantive hearing before the Court of Final Appeal, which includes a panel of distinguished overseas judges. Thus, apart from case law from both overseas domestic jurisdictions and international tribunals such as the European Court of Human Rights, the Human Rights Committee, the Committee Against Torture, the Inter-American Court of Human Rights, and the International Court of Justice, the courts have also freely referred to soft law such as General Comments and Concluding Observations of international treaty bodies, Reports of the Hong Kong Government to various international treaty bodies, the Siracusa Principles, the United States' Department of State's Country Reports on Human Rights Practice, as well as Brandeis-type of briefs on comparative legislation in the context of flag desecration law, ${ }^{14}$ or evidence of comparative medical research on sexual puberty in a claim for equality and privacy in relation to homosexual conduct, or the Joint Declaration in resolving a discrepancy in meaning between the English version and the Chinese version of the Basic Law. ${ }^{15}$ In Leung Kwok Hung $v$ HKSAR, the Court of Final Appeal relied partly on the Government's acceptance of a positive obligation in its period report to the Human Rights Committee pursuant to the ICCPR in upholding a positive obligation to assist the demonstrators to enjoy their right of peaceful assembly and demonstration. ${ }^{16}$

12 Sir Anthony Mason, "The Role of the Common Law in Hong Kong", in Jessica Young and Rebecca Lee (eds), The Common Law Lecture Series 2005 (Faculty of Law, The University of Hong Kong, 2006), at p 20. Sir Anthony specifically referred to Town Planning Board $v$ Society for the Protection of the Harbour Ltd (2004) 7 HKCFAR 1 as an example of the public looking to the court as an arena for ventilation of grievances and redress when such issues would normally have been addressed and resolved in the political process in other jurisdictions.

${ }^{13}$ See J Chan, "Hong Kong's Bill of Rights: Its Reception of and Contribution to International and Comparative Jurisprudence"(1988) 47 ICLQ 306; J Chan, "Basic Law and Constitutional Review: The First Decade"(2007) 37 HKLJ 407; J Chan \& C L Lim, "Interpreting Constitutional Rights and Permissible Restrictions", in J Chan \& C L Lim (eds), Law of the Hong Kong Constitution (Sweet \& Maxwell, $2^{\text {nd }}$ ed, 2015), Ch 17.

${ }^{14}$ HKSAR v Ng Kung Siu (1999) 2 HKCFAR 442.

${ }^{15}$ Leung TC William Roy v Secretary for Justice [2006] 4 HKLRD 211.

16 (2005) 8 HKCFAR 229, para 22. See also Ubamaka v Secretary for Security [2011] 1 HKLRD 359, para 359 (CA); Kong Yunming v Director of Social Welfare (2013) 16 HKCFAR 950, at paras 177-178. 


\section{Preserving the Integrity of the Common Law System}

Whenever constitutional powers are divided between two different jurisdictions, a classic problem is where and how to draw the dividing line. As an autonomous region, Hong Kong enjoys a high degree of autonomy except in the areas of foreign affairs and defence and matters concerning the relations of the Central Authorities and the HKSAR. This general principle itself is subject to expressed modifications in the Basic Law. Thus, Hong Kong enjoys, upon authorization, considerable degree of autonomy in participating in international events, maintaining and developing with foreign states and regions and international organizations, ${ }^{17}$ and even concluding international and regional treaties in specific fields - no doubt a reflection of the expansive international networks of Hong Kong as an international financial centre. At the same time, Hong Kong courts have no jurisdiction over acts of state and are bound by executive certificate on questions of facts concerning acts of state whenever such questions arise in the adjudication of cases. ${ }^{18}$ However, apart from such general principles, it is for the courts and the Central Authorities to work out on a case by case basis how the demarcation of jurisdictions is to be drawn. Not surprisingly, disagreement and conflicts could arise, and the Basic Law itself provides little guidance on how to address these disputes.

A unique feature of the Basic Law is that the power of final interpretation of the Basic Law is vested, not in the Court of Final Appeal, but in the Standing Committee of the National People's Congress ("NPCSC"). This stems from the fact that the HKSAR is not an independent entity but an autonomous region of the PRC. Under Article 158, in adjudicating a case, the Court of Final Appeal has a duty to refer, before rendering final judgment, a question of interpretation of the Basic Law to the NPCSC if the provision in question falls within the area of defence, foreign affairs and the relationship between the Central Authorities and the HKSAR and when the interpretation will decisively affect the judgments on the cases. As the Court of Final Appeal explained, this Article embodies two tests: the classification test, which means the provision in question has to be an excluded provision, and the necessity test, which means that the interpretation of the provision in question is necessary for the final disposal of the case before the court.

In $\mathrm{Ng} \mathrm{Ka}$ Ling $v$ Director of Immigration, the issue was whether the requirement of a certificate of entitlement, which could not be granted without an exit approval from the Mainland Security Bureau, for claiming a right of abode in Hong Kong was constitutional when there was no such requirement in the definition of the right of abode in Article 24 of the Basic Law. The Government relied on Article 22, which provides that any person from the Mainland to come to Hong Kong shall obtain the approval of the Central Government, to justify the certificate of entitlement system. Before the Court of Final Appeal, on the question of referral pursuant to Article 158, the court held that it was for the

${ }^{17}$ Art 151. The specific fields include economic, trade, financial and monetary, shipping, communications, tourism, cultural and sports fields.

18 Art 19. Examples of acts of state include defence and foreign affairs. 
court to decide whether the classification test and the necessity test were satisfied. For the purpose of argument, it was accepted that Article 22 was an excluded provision, and that Article 22 was arguably relevant to the interpretation of Art 24. The Government argued that in such case the court was obliged to refer the question of interpretation to the NPCSC. The court disagreed, holding that the proper test was, as a matter of substance, which was the predominant provision to be interpreted. This, it found, was Article 24, which concerned only domestic affairs. Article 22, which concerns central-local relationship, was relevant only in the background. Li CJ held:

"In our view, the test in considering whether the classification condition is satisfied is... As a matter of substance, what predominantly is the provision that has to be interpreted in the adjudication of the case? If the answer is an excluded provision, the Court is obliged to refer. If the answer is a provision which is not an excluded provision, then no reference has to be made, although an excluded provision is arguably relevant to the construction of the non-excluded provision even to the extent of qualifying it."

As the classification test was not satisfied, the Court held that there was no need to further consider the necessity test.

Where does this predominant provision test come from? It is by no means obvious from a plain reading of the text of the Basic Law. Professor Albert Chen forcefully criticized the approach of the court for being illogical. ${ }^{19} \mathrm{He}$ argued that (1) the court should first consider which provisions are necessary to be interpreted; (2) once the provisions have been identified, whether those provisions are excluded provisions. There was no basis for the application of a predominant provision test in applying the classification test.

While it is agreed that the court should first identify the provisions that are necessary to be interpreted before determining whether the relevant provisions are excluded provisions, this does not avoid the need to apply some kind of predominant provision test, albeit in the context of the necessity test. Indeed, Professor Chen himself admitted that in deciding which provisions need to be interpreted, the necessity test is only satisfied by those provisions which would be conclusive or substantially determinative of the outcome of the case before the court. It is unnecessary for the CFA to refer a question to the NPCSC for interpretation if the provisions that have to be interpreted are only marginally relevant. This is obviously desirable for protecting the integrity of the legal system in Hong Kong, for it is not difficult to imagine that a number of provisions in the Basic Law could be invoked in any Basic Law litigation. If the Court of Final Appeal has to make a reference whenever an excluded provision is

${ }^{19}$ Albert Chen, "The Court of Final Appeal's Ruling in the 'Illegal Migrant' Children Case: A Critical Commentary on the Application of Article 158 of the Basic Law", in Johannes Chan, H L Fu and Yash Ghai (eds), Hong Kong's Constitutional Debate: Conflict over Interpretation (Hong Kong University Press, 2000), pp 73-141. 
invoked and arguably relevant to the final decision of the case, this would be a substantial derogation from the autonomy of the HKSAR. Professor Chen argued that this would not be the case, as the NPCSC was only asked to interpret the meaning of the excluded provision, and it was for the court to adjudicate on other provisions and to apply the interpretation to the case. This explanation is formal rather than practical, for if the excluded provision is crucial to the disposition of the case, once an interpretation is made, there is little room left for the Court to decide. In the $\mathrm{Ng} \mathrm{Ka} \mathrm{Ling} \mathrm{case,} \mathrm{once} \mathrm{the} \mathrm{NPCSC} \mathrm{decided} \mathrm{that} \mathrm{"people}$ from other parts of China" in Article 22 of the Basic Law included "Mainland residents who have acquired the status of HK Permanent Residents by virtue of Article 24 upon the commencement of the Basic Law and who would like to come to Hong Kong to take up their right of abode", it follows that the applicants in the case would need an exit approval and therefore a scheme which requires an exit approval would be constitutional. ${ }^{20}$

Therefore, whenever a few provisions of the Basic Law are invoked in a case before the Court of Final Appeal, the Court would have to decide which provisions are "necessary" to be interpreted in the sense that their interpretation would be determinative of the outcome of the case. This is not always a straight forward exercise. As the Court pointed out, one provision may qualify another provision by way of addition, subtraction or modification, or it may lend colour to the meaning or provide a pointer to the interpretation of another provision. Save in the most straight forward cases, the reference to the NPCSC may not be just the meaning of the excluded provision, for the interpretation has to be made in context, the context being its relations with the other provisions which are not excluded provisions. Hence, a referral most likely means that the NPCSC would effectively determine the outcome of the case, and may even affect other applicable legal principle. ${ }^{21}$ As a result, the threshold for referral has to be high so that the necessity test is satisfied only when the interpretation of the provisions are determinative of the outcome of the case. If a few provisions are involved, the court will have to decide which provisions the interpretation of which would be determinative and which provisions the interpretation of which would only be relevant but not determinative. The power to make this decision, if the Hong Kong legal system is to retain its autonomy and to avoid any abuse of the referral procedure, must rest with the Hong Kong courts. The rule of law depends on that. Whether it is called a predominant provision test or a conclusive effect test, the mischief to be avoided is the same, namely to safeguard the integrity of the common law system in Hong Kong. It must also be borne in mind that the interpretation by the NPCSC is essentially a political process without any transparency. Its interpretation is not constrained by legal consideration or the rule of evidence. It is only right for a court at the highest level to act cautiously in giving up its jurisdiction in the process of its adjudication to a political body to effectively determine the

20 See Albert Chen, supra, at p 133. The same is true in the Congo case, see below. ${ }^{21}$ For instance, in Democratic Republic of the Congo $v$ FG Hemisphere Associates $L L C$ (No 1) (2011) 14 HKCFAR 95, the effect of the NPCSC interpretation is that the common law rule on relative immunity is found to be inconsistent with the Basic Law and hence does not form part of the law of the HKSAR. 
outcome of the case. What underlies the reasoning of the court is a higher principle that the constitutional jurisdiction of the courts must be vigilantly safeguarded in order to maintain the integrity of the legal system.

Although the Court of Final Appeal in $\mathrm{Ng} \mathrm{Ka}$ Ling held that it was not necessary to refer any question to the NPCSC for interpretation, the HKSAR Government sought such an interpretation on the basis that the judgment of the Court caused considerable difficulties for Hong Kong, as a large number of Mainland born children would as a result acquire a right of abode in Hong Kong. In June 199, the NPCSC issued an interpretation that effectively reversed the judgment of the Court. ${ }^{22}$

The NPCSC interpretation has cast considerable doubt over the independence of the judiciary and the integrity of the Hong Kong legal system. The interpretation is primarily a political decision that was made without any transparency. There were concerns whether the judiciary could remain independent if its final judgments could be reversed by a political organ across the border, and how independence of the judiciary could reconcile with the NPCSC interpretation, which is constitutional within the Mainland legal system. This question was addressed in Chong Fung Yuen v Director of Immigration. ${ }^{23}$ The issue in that case was whether a child born in Hong Kong to parents neither of whom was a Hong Kong Permanent Resident would acquire a right of abode in Hong Kong. In no uncertain term the Court of Final Appeal dispelled any concern that a judge would have to look over his shoulder to take into account possible responses from the NPCSC in discharging his judicial duty. It held that the courts in Hong Kong are bound to apply the common law, and not the principles in the Mainland system, in interpreting the Basic Law. Under the common law, the courts' role is "to construe the legislative intent of the Basic Law as expressed in the language. Their task is not to ascertain the intent of the lawmaker on its own. Their duty is to ascertain what was meant by the language used and to give effect to the legislative intent as expressed in the language." 24 The language was not looked at in isolation but in light of its context or purpose, and the courts must avoid a literal, technical, narrow or rigid approach. At the same time, the courts could not give the language a meaning which it could not bear. In interpreting the Basic Law, while the courts may resort to extrinsic materials, such as the Joint Declaration and the Explanations on the draft Basic Law before its enactment, that throw light on the context or purpose of the Basic Law, the courts have to be cautious and should adopt a particularly prudent approach in considering post-enactment materials. ${ }^{25}$ This point is of particular significance as the NPCSC in its interpretation reversing $\mathrm{Ng} \mathrm{Ka} \mathrm{Ling} \mathrm{stated} \mathrm{that} \mathrm{the} \mathrm{intent} \mathrm{of}$ the Basic Law could be found in a report of the Preparatory Committee, which was set up six years after the enactment of the Basic Law for the purpose of

\footnotetext{
22 For a detailed discussion, see Johannes Chan \& C L Lim, Law of the Hong Kong Constitution, supra, paras 2.080-2.093; Johannes Chan, H L Fu and Yash Ghai (eds), Hong Kong's Constitutional Debate: Conflict over Interpretation, supra. 23 (2001) 4 HKCFAR 211.

24 Ibid, at 223.

25 Ibid, at 224-225.
} 
preparing for the establishment of the HKSAR. The Court in Chong Fung Yuen held that this report could not affect the interpretation of a provision when the meaning of its language is clear, alongside an expression of doubts of the relevance and the appropriateness of considering such extrinsic pre-enactment materials in any event.

With regard to the NPCSC interpretation, the Court respected the power of the NPCSC to interpret the Basic Law under Art 67(4) of the PRC Constitution and Art 158 of the Basic Law, but held that this power operated in a different system and was legislative, and not judicial, in nature. Once an interpretation has been made, it is binding on the Hong Kong courts and forms part of the system in the HKSAR. Yet before an interpretation has been made, the courts need only refer to the common law in interpreting the Basic Law. Even after an interpretation has been made, the courts will still have to ascertain the scope of the interpretation. Accordingly, the Court found that some remarks on the nature of Art 24 in the previous NPCSC interpretation was confined to the context of that interpretation and was not binding on the Court in interpreting a different subsection of the same provision in a different context. Having held that the provision before the Court was not an excluded provision, the Court rejected the Director's application for making a judicial reference to the NPCSC. ${ }^{26}$

Chong Fung Yuen is important, not only in restoring public confidence in the independence of the judiciary after the first NPCSC interpretation, but also in the Court's innovative approach of characterizing the NPCSC interpretation, which operates in a different system, as legislative in nature and therefore providing a theoretical justification for the Hong Kong judiciary to legitimately exclude any consideration of possible responses from the legislative organ of a different legal system in interpreting the Basic law. It is clear that the protecting the integrity of the common law system is a crucial constitutional principle, if not the raison ete, of the judgment. The point was made even more explicit in the subsequent case of Vallejos $v$ Commission of Registration, ${ }^{27}$ where the Court of Final Appeal refused to make a judicial reference for the NPCSC on the ground that the necessity test for referral was not satisfied. The Court emphasized that the question for interpretation had to be arguable. An argument that is plainly and obviously bad would not be arguable. The Chief Justice pointed out that "the arguability factor is implicit in Art 158(3) to ensure integrity in the operation of a reference. Otherwise, there will be a risk of potential abuse; all sorts of fanciful arguments could then be made just to seek a reference to the Standing Committee."28 The Court has to be cautious in making any judicial reference, not only because it is charged with the responsibility of making final adjudication of cases on its own, but also because there is the "long established rule that a common law court cannot abdicate any part of its judicial function to any other body." 29

\footnotetext{
${ }^{26}$ Ibid, at p 229.

27 (2013) 16 HKCFAR 45, at paras 103-112.

28 Ibid, para 104.

29 Ibid, para 106.
} 
The same invisible principle can be discerned in the Congo case, ${ }^{30}$ although this is a more difficult case to fit into the pattern. In that case, the plaintiff sought to enforce an arbitral award against the Government of Congo Republic in Hong Kong against certain payment that was due by a PRC state owned enterprise to the Congo Government under a separate mining agreement. The Congo Government resisted the proceeding by raising sovereign immunity in Hong Kong courts. The common law position is that sovereignty immunity is not applicable if the foreign government is engaged in a transaction of a commercial nature ("the restrictive immunity principle"), whereas the foreign policy of China is to accord a foreign state an absolute immunity in her domestic courts. Does the issue involve an application of the common law principle, or does it involve "an act of state such as foreign affairs" within the meaning of Articles 13 and 19 of the Basic Law so that it falls outside the jurisdiction of the Hong Kong courts? The Court of Appeal held that state immunity was a matter of common law. The Court of Final Appeal by a 3 to 2 majority reversed this decision. The majority held that in a unitary state, the practice or the doctrine of state immunity applied uniformly across the state, and that the executive and the court had to speak with one voice on the policy of state immunity. Under the Basic Law, the responsibility for foreign affairs was a matter exclusively for the Central Government. The doctrine of state immunity was concerned with relations between states and hence fell within the scope of foreign affairs, over which the Hong Kong courts had no jurisdiction. Accordingly, the Court of Final Appeal decided, for the first time, to refer to the NPCSC a number of questions for its interpretation. Further, the common law on state immunity was overridden by the Basic Law to the extent of inconsistency with the PRC foreign policy.

The minority disagreed, holding that the issue before the court was a matter of common law and should be decided by the Hong Kong court. They drew a distinction between recognition of a foreign state, which was a matter for the executive on which one voice was desirable if not essential, and the extent of immunity available in courts, which was a matter of law to be determined by the judiciary. Therefore, whether the immunity was absolute or restrictive, it was a matter of law for the courts. The determination of this question did not involve any exercise of jurisdiction over acts of state, defence or foreign affairs; nor did it involve the interpretation of any provision of the Basic Law.

In considering the arguments, the Court of Final Appeal was heavily influenced by three letters that were placed by the Office of the Commissioner of the Ministry of Foreign Affairs ("OCMFA") before the courts at various stages. The $1^{\text {st }}$ letter, which was placed before the Court of First Instance, addressed solely the position of the PRC on state immunity. The $2^{\text {nd }}$ letter, which was placed before the Court of Appeal, explained the unchanged position of the PRC despite her ratification of the UN Convention on Restrictive Immunity, which has not come into effect. The Court of Appeal held that there was no evidence to show that a restrictive immunity doctrine would jeopardize or prejudice any state interest. So, a $3^{\text {rd }}$ letter was placed before the Court of Final Appeal which

30 Democratic Republic of the Congo v FG Hemisphere Associates LLC (No 1)(2011) 14 HKCFAR 95. 
identified the prejudice to the sovereignty of the Chinese state had the doctrine of restrictive immunity been adopted in Hong Kong. Unlike the two previous letters, the $3^{\text {rd }}$ letter was drafted in strong language and tone. ${ }^{31}$ This has prompted Bokhary PJ to extract a concession from the Secretary for Justice that the letter was to draw the court's attention to the policy of the PRC and not to dictate a result. ${ }^{32}$ The tone of this letter was clear that were the court to adopt the doctrine of restrictive immunity, such decision would likely be reversed by an interpretation of the NPCSC. 33

The precise status of these three letters was unclear. Under Art 19 of the Basic Law, it is possible for the Chief Executive to certify certain questions of fact concerning acts of state whenever such questions arise in the adjudication of cases. Such certificate shall be binding on the courts and be treated as conclusive proof of the facts stated therein. No such certificate has been issued in this case. Indeed, the Court itself held that it was unnecessary to do so, as these letters would constitute such certification. This is hardly satisfactory. The fact of state, as it is known, is a procedure to introduce statements of fact which shall be treated as conclusive proof by the court. The purpose is to ensure a proper way of introducing conclusive evidence into the court and a certain formality is required. If a letter from OCMFA can constitute such conclusive proof, does it suggest in future any letter from any government department of the Central Authority could constitute such conclusive proof? It may be a formality in this case, as it is hardly thinkable that the Chief Executive will not provide a certificate to this effect if requested. Yet the formality is there to avoid any undue pressure to be exerted on the court directly by any department of the Central Government.

Thus, in light of the clear position of the Central Government, the Court was faced with only limited options. First, it may decide to refer the question of interpretation to the NCPSC, as it has chosen to do, and the outcome is certain that there would be absolute immunity and the common law of restrictive immunity would be reversed. Secondly, it may decide to go along with the minority to decide the case on the common law principle of restrictive immunity and not to refer the question to the NPCSC. Its decision would then most likely be reversed by a subsequent NPCSC interpretation. This would be the exact replication of the $\mathrm{Ng} \mathrm{Ka} \mathrm{Ling} \mathrm{situation} \mathrm{and} \mathrm{may} \mathrm{have} \mathrm{a} \mathrm{detrimental} \mathrm{effect} \mathrm{on} \mathrm{the}$

31 The letter was reproduced in para 211 of the Judgment.

${ }^{32}$ See para 91 of the Judgment. See also para 294 where the majority expressed the same view.

${ }^{33}$ See Eric Cheung, supra. Benny Tai argued that as a result, the Court made a calculated decision to make a reference in order to minimise the damage that could have been done to judicial independence by a subsequent adverse interpretation from the NPCSC, given that the context of this case was not political and the issue of foreign affairs was obviously arguable: see Benny Tai, "The Constitutional Game of Art 158(3) of the Basic Law" (2011) 41 HKLJ 377. This is an interesting observation but it does not explain why the court could not just go through the common law route without seeking an interpretation and decide that the common law of restrictive immunity has to be modified. 
Hong Kong legal system. There would also be uncertainty on how far the scope of the NPCSC interpretation would be in such circumstances, especially when the NPCSC interpretation could not affect judgment previously rendered and then the Congo Government would come within the jurisdiction of the Hong Kong court despite the NPCSC interpretation. Thirdly, the Court may avoid the issue of sovereign immunity by holding that whatever be the position on sovereign immunity, the Congo Government had waived its immunity by defending these proceedings. ${ }^{34}$ While this is a perfectly defensible position and may be a less controversial route, it may not be an attractive solution as the Central Government is keen not to exercise any jurisdiction over the Congo Government. The consequence of this option would still likely be a reversal of the Court's decision by a subsequent NPCSC interpretation.

There was apparently a fourth option. The majority of the Court of Final Appeal accepted that restrictive immunity represented the common law before the changeover. ${ }^{35}$ Under Article 8 and 160, the common law is preserved save to the extent that it is inconsistent with the Basic Law, and may be subject to such modifications, adaptations, limitations or exceptions as are necessary so as to bring them in conformity with the status of Hong Kong after the change of sovereignty. ${ }^{36}$ Instead of deciding that the doctrine of state immunity is an act of state and therefore falls outside the jurisdiction of the Hong Kong courts, the majority could have decided, as did the minority, that the extent of state immunity is a matter of common law, which has to be modified to reflect the status of Hong Kong as part of a unified state that adopts the policy of absolute immunity. In this way, the court could have reached a position that the common law principle in Hong Kong after 1997 is no longer restrictive immunity but absolute immunity, and therefore it would be unnecessary to refer any question of interpretation to the NPCSC. ${ }^{37}$ On this basis, it would decline jurisdiction over

34 The dominant position in international law is that mere agreement to arbitration does not mean that there is also waiver to the enforcement of the arbitral award. This position is hardly defensive as a matter of fairness.

35 At para 221 of the Judgment.

36 Decision of the NPCSC on the Treatment of the Laws Previously in Force in Hong Kong in accordance with Article 160 of the Basic Law, referred to at para 313 of the Judgment.

37 See Yap Po Jen, "Why Absolute Immunity Should Apply but a Reference was Unnecessary?"(2011) 41 HKLJ 391. Yap argued that the one voice policy cases could be distinguished because the executive in Britain had not spoken with another voice, whereas the Secretary for Justice in Hong Kong has spoken with a different voice. It is true that the executive in Britain had not expressed a different view and therefore left the matter of determining the extent of immunity to the court, it does not follow that if the executive has spoken the one voice policy has to be adopted. To make this argument one would have to accept that the determination of state policy on immunity is a matter outside the jurisdiction of the court, an argument which Yap has expressed doubt. As Cheung pointed out, China has entered into over 100 bilateral agreements that have adopted the position of restrictive immunity and it would be absurd to suggest that there was one voice: see Eric Cheung, "Undermining Our Judicial 
the Congo Government and this option would serve both the interest of China and the interest of protecting the integrity of the common law system.

Instead, the majority chose to refer to the NPCSC a question of interpretation of Art 13 and 19 of the Basic Law. Arguably Article 13, which provides that the Central Government shall be responsible for foreign affairs, is never an issue. There is no dispute of this fact. The question is, notwithstanding this, whether the doctrine of state immunity is nonetheless a matter of common law that could be decided by the Hong Kong courts. Article 19, which provides that the court has no jurisdiction over acts of state such as foreign affairs, comes closer, and the effect of the NPCSC interpretation is that the court would have to forgo jurisdiction in future whenever state immunity is raised. ${ }^{38}$ This is so even when state immunity is raised by a state that has subscribed to the principle of restrictive immunity. The position would have been the same if the Court decided that the common law is now one of absolute immunity. This retrograde position seems like an awkward option for the court to adopt. It would be even more awkward when the UN Convention on Restrictive Immunity, to which China has ratified, comes into effect. Would the common law have to be changed again? Thus, instead of surrendering itself to such a dire position, the majority may consider that this position is best assigned to the One Country component and therefore leaving the Two Systems component out of it. This is an ironic position to take. Admittedly the Court has to balance between respecting the PRC sovereignty and limiting the harm to the common law system. In choosing to make a judicial referral, the courts may protect the purity of the common law but may also have inadvertently given up jurisdiction in relation to what constitutes foreign affairs in future. It is not, for the purpose of this paper, to say that judicial referral is a desirable approach, indeed much to be said to the contrary as expressed in the powerful minority judgments, but rather to explain that the majority of the Court may probably consider it to be the least detrimental position to adopt in the circumstances and hence the decision could still be explained, perhaps equally ironically, by the higher principle of keeping the integrity of the common law system!

In deciding to make a reference to the NPCSC, the Court of Final Appeal laid down certain parameters. First, it declined to decide the question of referral as a preliminary issue. Instead, it insisted on hearing full arguments on the merits of the case on the ground that whether certain provisions are necessary and determinative of the outcome of the case could only be fully appreciated when the court was appraised of the merits of the case. Secondly, the court, after hearing the parties, formulated the questions that it required the NPCSC to interpret. This will define the scope of the interpretation. Although such questions are technically not binding on the NPCSC, the NPCSC did give its

Independence and Autonomy" (2011) 41 HKLJ 411. The court accepted that it has to take into account the state policy in determining the content of the common law principle of state immunity. Thus, it is open to the court to take into account the absolute immunity principle of the PRC and modify the common law in Hong Kong accordingly.

38 See P Y Lo, "The Gateway Opens Wide" (2011) 41 HKLJ 385. 
interpretation within the framework of these questions. Thirdly, the court itself also rendered a provisional judgment on the issue. It is provisional as it is subject to the interpretation of the NPCSC. The provisional judgment was placed before the NPCSC so that the NPCSC has the benefit of the views of the highest court before it renders its interpretation. This is important in another aspect. The parties to the litigation do not have any right to appear before the NPCSC, yet its interpretation is determinative of the outcome of the case. By allowing the parties to make full submissions on the merits and by giving a provisional judgment, the Court has at least afforded the parties a full and fair hearing, even though its decision is not final. Given that there is no right of audience before the NPCSC, this procedure affords the best the Hong Kong legal system could provide to ensure a fair hearing.

None of these procedures are set out in the Basic Law. The purpose of drawing up these procedures is obviously an attempt to minimize the arbitrariness of the NPCSC interpretation and in turn, to protect the integrity of the legal system in Hong Kong. The invisible constitutional principle is at work again.

\section{Continuity of the Previous System v A Living Tree Principle}

A constitution should serve its community, and the community changes with time. Thus, the constitution should be able to evolve to respond to social changes. It should be a living tree that is capable of growth and development, and should not be stunt by historical relics. As Justice Bertha Wilson nicely put it, "a constitution is always unfinished and is always evolving... [It is like a] chain novel where generations of judges produce their respective chapters. Each judge is constrained to a degree by what has gone on before, but at the same time is obliged to make the novel the best that it can be."39

At the same time, the Basic Law expressly provides that the previous capitalist system and way of life shall remain unchanged for 50 years. ${ }^{40}$ The preservation of the previous social, economic and legal system was of great importance in maintaining the confidence of the people in Hong Kong in the future at a time of great uncertainty when the Joint Declaration was signed in 1984, and continues to be of importance as Hong Kong is moving towards the end of the guaranteed period of 50 years, which will expire in 2047. This theme of continuity with the previous system, which does not always sit well with the

39 B Wilson, "The Making of a Constitution: Approaches to Judicial Interpretation" [1988] PL 370 at 372. The famous chain novel analogy comes from Professor Ronald Dworkin, Law's Empire (Belknap, 1986). ${ }^{40}$ Art 5. This article does not mean that the system has to be changed after 50 years. The position in 2047, when the guaranteed period of 50 years expires, is unclear at this stage. For other provisions that refer to the preservation of the previous system, see, for example, 103 (public servants), 136 (education system), 142 (professional qualifications), 144 (subvention for nongovernmental organizations), and 145 (social welfare system). 
living tree characteristics of the Basic Law, has come up in a number of cases, and has on some occasions produced awkward consequences.

In Association of Expatriate Civil Servants of Hong Kong $v$ Chief Executive of the HKSAR, ${ }^{41}$ the applicants argued that the procedures for the appointment and dismissal of public servants must be established either by legislation or with legislative approval, as Art 48(7) of the Basic Law requires the Chief Executive to appoint or remove holders of public office "in accordance with legal procedure", whereas the Public Service (Administrative) Order 1997 and the Public Service (Disciplinary) Regulation were executive orders only. The Government relied on Art 103 of the Basic Law, which provides that "Hong Kong's previous system of recruitment [and] ... discipline... for the public services ... shall be maintained." Keith J held that since the previous procedures for the recruitment and dismissal of holders of public officers were established by the Crown under the Hong Kong Letters Patent and the Colonial Regulations in the exercise of its prerogative, and by the Governor in the exercise of powers expressly conferred upon him by the Colonial Regulations, the maintenance of the previous system did not require the current system to have the approval of the Legislature. Insofar as the phrase "in accordance with legal procedure" in Art 48(7) was concerned, this phrase has to be construed together with Art 103 and simply means a procedure established lawfully rather than a procedure to be established by law. Since the procedures laid down by the Chief Executive in the Order and the Regulation maintained Hong Kong's previous system of recruitment and discipline of the public service and were lawfully established, they satisfied the requirement of "in accordance with legal procedure". Although this phrase appears a few times in the Basic Law, Keith J held that "the meaning of a particular provision, whether in an ordinance or in a constitutional instrument such as the Basic Law, depends very much on its context", and the learned judge did not discern a clear pattern as to the rationale behind the use of one phrase and not another in the Basic Law.

Keith J's decision was distinguished by Hartmann J (as he then was) in Leung Kwok Hung $v$ Chief Executive of the HKSAR. ${ }^{42}$ In that case, the issue was whether an executive order setting out the procedure for applications for the approval of interceptions of telecommunications complied with the requirement of "in accordance with legal procedure" in Art 30 of the Basic Law. Hartmann J emphasized that the context in which this phrase was to be interpreted was very different from that in Art 48(7), as Art 30 was concerned with the protection of a fundamental right of privacy. Such context required a different interpretation. Hartmann J held:

"149. In my view, it is a formalistic outcome to say that the fundamental right contained in art.30, which the article requires shall be protected by law, may nevertheless be restricted by a body of purely administrative

41 [1998] 1 HKLRD 615.

42 HCAL 107/2005, upheld on appeal: CACV 73 and 87/2006. In the further appeal to the Court of Final Appeal, the issue of the legality of the executive order was no longer pursued: (2006) 9 HKCFAR 441 (sub nom Koo Sze Yiu v Chief Executive of the HKSAR). 
procedures which are not law and which bind only public servants who, in the event of abuse, are subject only to internal disciplinary proceedings. That, in my view, would derogate substantially from the practical and effective value of the right guaranteed by the article. That, I am satisfied - giving the article a generous interpretation in order to protect the full measure of the value of the right it guarantees - cannot have been the intention of those who drafted the Basic Law.

150. I am satisfied, therefore, that the use of the phrase in accordance with legal procedures' in art 30 means procedures which are laid down by law in the sense that they form part of substantive law, invariably in order to comply with the requirements of legal certainty, within legislation, primary and/or secondary."

The distinction is not satisfactory. It is difficult to see why invasion of privacy has to be provided by law whereas disciplinary action that could have resulted in the removal of a public servant from employment and a substantial loss of pension benefit could be prescribed by administrative procedures. Loss of livelihood would have been the concern of a far higher number of ordinary people than occasional covert surveillance carried out by law enforcement agents. A plausible explanation is that the disciplinary system is a continuation of the previous system, and it is such an overriding principle that the court would be hesitant to upset the system by demanding legislative intervention.

This argument was reinforced in Kong Yunming $v$ Director of Social Welfare. ${ }^{43}$ At issue was whether a substantial change of the residence requirement from 1 year to 7 years for Comprehensive Social Welfare Assistance (CSSA) was a violation of the Applicant's pre-existing right to social welfare under Art 36 of the Basic Law. The CSSA scheme is a non-contributory, meanstested social security scheme that is aimed at providing a safety net for people who are unable to meet their basic needs. Like all forms of social security in Hong Kong, the CSSA scheme has all along been a non-statutory scheme and is administered by the Social Welfare Department. The Department has issued guidelines which set out the criteria, the procedure for application and even a system of administrative appeal against refusal to provide CSSA. It is not in dispute that these guidelines are administrative in nature and are generally accessible. One of the issues is whether a restriction on the right to social welfare that was imposed administratively satisfied the requirement of Art 36, which provides that "Hong Kong residents shall have the right to social welfare in accordance with law."

Both the Court of Appeal and the Court of Final Appeal were concerned of the implications of a requirement of restrictions by law on the social welfare system. At the Court of Appeal, Stock VP noted that Art 36 did not set out any type of social welfare or any level of benefits that a person might enjoy. Nor did it provide for any restriction of the right or the type of restriction that could be imposed. The learned judge then argued that any social welfare must carry with

43 (2013) 16 HKCFAR 950. 
it eligibility conditions. These eligibility conditions should not be regarded as restrictions, and accordingly, the question of restrictions in accordance with law did not arise. ${ }^{44}$ Alternatively, the Court relied on Art 145, which provides that "[o]n the basis of the previous social welfare system, the Government of the HKSAR shall, on its own, formulate policies on the development and improvement of this system in the light of the economic conditions and social needs." It was held that Art 145 itself provided the legal basis; that "the qualifying conditions may justifiably be described as prescribed by law in that they are authorized by article 145 itself, are accessible, establish rules of general application and do not permit arbitrary or random decision-making." 45 On the first ground, the distinction between eligibility condition and restriction is a semantic distinction without any difference in substance. In any event, the UN Human Rights Committee has commented that "any qualifying conditions for benefits must be reasonable, proportionate and transparent. The withdrawal, reduction or suspension of benefits should be circumscribed, based on grounds that are reasonable, subject to due process, and provided for in national law." 46 Thus, the restriction will still have to satisfy the proportionality test whether it is described as a restriction or an eligibility condition. On the second ground, if Art 145 provides the legal basis, the requirement of "in accordance with law" is tautological and practically meaningless.

Surprisingly, this reasoning was endorsed by the Court of Final Appeal, which resorted to the "previous system". Ribeiro PJ held: ${ }^{47}$
"Article 145 recognizes and endorses the validity of "the previous social welfare system" which consisted of a non-statutory system of administrative rules and policies. Accordingly, reading art 36 together with art 145, the intention of the Basic Law must be taken to be that such administrative system - consisting of rules that are accessible, systematically applied and subject to a process of administrative appeal - is to be treated as a system providing "social welfare in accordance with law" within the meaning of art 36."

This reasoning is hardly convincing. Article 145 provides a framework to enable the Government to formulate social welfare policies in accordance with the changing economic conditions. It is at least not clear that Article 145 also endorses an administrative scheme, which would have made a mockery of the requirement of "in accordance with law" in Art 36. Though the Court of Final Appeal did not agree with the Court of Appeal that Article 36 did not provide any substance other than a right not to be discriminated in the enjoyment of social

${ }^{44}$ CACC 185/2009 (CA, 17 Feb 2012), paras 53, 73-74.

45 Ibid, para 74.

46 General Comment No 19, para 24.

47 (2013) 16 HKCFAR 950, para 25, though the Court of Final Appeal did not accept the first reason on a distinction between eligibility condition and restriction. For a commentary, see Simon Young, "Does it matter if restrictions on the right to social welfare in Hong Kong are prescribed by law or policy?" (2014) 44 HKLJ 25. 
welfare rights, the Court of Final Appeal did share the concern that social welfare system had to cater for a wide range of clients in a wide range of different circumstances and therefore it was better served by a flexible, transparent and predictable administrative system rather than by having each benefit spelt out through a legislative process. ${ }^{48}$ Yet the desirability for flexibility in administering a social welfare system is not unique to Hong Kong, and many other jurisdictions have found no impediment to introduce a statute on social welfare. ${ }^{49}$ The facts that the administrative rules are accessible, systematically applied and include an administrative appeal system to reduce arbitrariness in the decision-making process do not by themselves turn an administrative scheme into law. The requirement of "in accordance with law" is not formalistic. It serves an important democratic value that any restriction of a fundamental right has to be properly debated and scrutinized by the people's representatives in the Legislature. ${ }^{50}$ To regard an administrative scheme as "law" will defeat the important function of legislative scrutiny and is inconsistent with the approach of the court in adopting a wide margin of appreciation. In justifying a wide margin of appreciation, the Court relied heavily on legislative scrutiny because social and economic policies were better judged by the legislature than by the court. ${ }^{51}$ Yet by accepting an administrative scheme as "law", the court leaves no room for legislative scrutiny! It appears that the rather loose requirement on legislative sanction could only be explained partly by the judicial perception of the nature of social and economic rights, an issue that we will come back later, and partly by the eagerness to uphold an invisible principle of continuation of the previous system. The Court was reluctant to upset the previous administrative social welfare scheme that has been in place for many years by imposing a requirement of legal framework.

Another significant implication of the continuity principle in this case is the determination of the scope of the right to social welfare. The Court of Appeal has great difficulty in defining the scope of the right under Art 36, which eventually led to its rejection of any substantive right under Art 36 save for a right not to be discriminated in the enjoyment of the right to social welfare. The Court of Final Appeal accepted that the right that received constitutional protection under Art 36 would be the rights as defined by the rules of eligibility

\footnotetext{
48 At para 27.

${ }^{49}$ For example, see the UK Social Security Act, the Australian Social Security Act, 50 See "The Word 'Law' in Article 30 of the American Convention on Human Rights", Advisory Opinion, OC-6/08, Inter-American Court of Human Rights, Series A, No 6 (9 May 1986), paras 21-22.

${ }^{51} \mathrm{See}$, for example, the judgment of Cheung CJHC at the Court of First Instance, para 56. See also the judgment of the Court of Final Appeal in Fok Chun-wa $v$ Hospital Authority (2012) 15 HKCFAR 409 at para 63-64, where the Court held, in the context of justifying the concept of a wide margin of appreciation, that "where matters of state or community policy are concerned, these are matters predominantly for the Executive or the Legislature."
} 
on the date of establishment of the HKSAR, namely 1 July $1997 . .^{52}$ In order to determine progression or retrogression under Art 145, there has to be a baseline for assessment. The obvious, and perhaps the only sensible, baseline would be the rights as existed at the time when the HKSAR came into being. What the applicant was entitled to on that date included the then eligibility condition, namely the 1-year residence requirement. Nothing more, nothing less. Thus, in one stroke, the Court constitutionalized the social welfare rights (and conditions) as existed on 1 July 1997, and any further restriction from that level of social welfare benefits has to be justified. ${ }^{53}$

In contrast, the courts are well aware of the sensitivity of fossilizing the previous system, and in this regard, they have drawn a distinction based on whether a fundamental right was engaged. In Catholic Diocese of Hong Kong $v$ Secretary for Education, ${ }^{54}$ the issue was whether the introduction of a schoolbased management scheme by the Government, which has the effect of diluting the control of the church in the management board of government-aided schools run by the Catholic Church, was in violation of the right of the religious organization to continue to run its schools "in accordance with the previous practice", contrary to Art 141 of the Basic Law. The Applicant argued that the "previous practice" embodied an exclusive control over the appointment of the school management committee, the supervisor and the principal of its schools. The argument failed, firstly on factual grounds that the previous system did allow the Director of Education to require binding constitution and appoint managers, and that the new system did leave religious organizations free to nominate a majority of the persons serving on the management committees of the aided schools that it sponsored. It also failed on the ground that the "previous practice" could not prevent the Government from making changes. Art 141 was to preserve the continuity of the previous system, but it did not prevent changes to individual elements of the system. ${ }^{55}$ On the other hand, this phrase did protect religious organizations to run their schools in accordance with the previous practice insofar as it involved the exercise of their right to religious belief and religious activities, such as morning prayers or religious instructions, but constitutional protection was not engaged in relation to policies that had no religious content. Thus, the concept of previous practice is extended to cover religious rights and freedom in the education context, and yet it allows the education system to be further developed in light of changing social conditions.

\footnotetext{
52 See paras 34-35. See also Catholic Diocese of Hong Kong v Secretary for Justice (2011) 14 HKCFAR 754, at para 45 for a similar holding that the previous education system refers to the system in place just before 1 July 1997.

53 Bokhary PJ, in his separate judgment, held that if any restriction is to be justified by economic downturn, it has to be so dire as to bring about a situation not contemplated by the constitution, or otherwise Art 145 would be of little practical use: see para 160. See also Albert Chen, “'A Stroke of Genius' in Kong Yunming" (2014) 44 HKLJ 7.

54 (2011) 14 HKCFAR 754.

55 At para 61-62. See also Secretary for Justice v Lau Kwok Fai ((2005) 8 HKCFAR 304 , at para 66.
} 
The theme of continuity has also been invoked in rejecting an argument to outlaw some administrative tribunals such as the Market Misconduct Tribunal or the Inland Revenue Board on the ground that they had usurped powers which were reserved for the judiciary. ${ }^{56}$ Administrative tribunals have played an important and valuable role in Hong Kong. Bearing in mind the theme of continuity in the Basic Law, it was held that there has to be very compelling and sound reasons before it could be concluded that the vesting of judicial power in the judiciary under Art 80 of the Basic Law would have the effect of outlawing these tribunals and rendering their statutory jurisdiction unconstitutional for having ousted the jurisdiction of the judiciary or usurped the judicial functions of the courts.

On the other hand, the same theme has also been invoked in justifying restrictions of constitutional rights. It was invoked in justifying legislative action to reduce the pay of civil servants, as the threat of legislative intervention in employment contract with the Government was a feature in the pre-1997 regime. ${ }^{57}$ Likewise, corporate voting in the functional constituency system, under which corporations are entitled to vote in functional constituencies to return a member in their constituency to the Legislative Council, was justified on the ground that this system, albeit some distance away from full democracy, represented a feature in the previous political system and has to be considered in its historical context. Accordingly, the Court of Appeal held that the right to vote in Art 26 of Basic Law did not preclude corporate voting. ${ }^{58}$ It is not the purpose of this paper to argue whether the theme of continuity should only be used to advance constitutional entitlements, but rather to show that this invisible principle does play a part in constitutional interpretation.

\section{Separation of Powers}

One of the perennial debates in Hong Kong is the nature of the governance system. The Mainland authorities keep describing Hong Kong as an "executiveled system", meaning that both the Legislature and the Judiciary are to support and not to challenge the Executive Government, and accordingly leaves no room for checks and balances against excesses by the Executive Government. This phrase of "executive-led government" appears nowhere in the Basic Law, but it is contended that the former colonial system under which the Governor enjoyed practically unchecked powers is to be preserved in the HKSAR. This is partly because the former system is regarded as highly efficient, and partly because it is much easier for the Mainland authorities to maintain control on the development of Hong Kong through an appointed Chief Executive. On the other hand,

56 Koon Wing Yee v Insider Dealing Tribunal [2013] 1 HKLRD 76, at para 59; (2008) 11 HKCFAR 170 (CFA); Luk Ka Cheung v Market Misconduct Tribunal [2009] 1 HKC 1, para 35; Lee Yee Shing Jacky v Inland Revenue Board [2011] 6 HKC 307, para 98.

57 Secretary for Justice v Lau Kwok Fai ((2005) 8 HKCFAR 304.

58 Chan Yu Nam v Secretary for Constitutional and Mainland Affairs, CACV 2 \& 3/2010 (7 Dec 2010). 
preservation of the colonial system is incompatible with a number of features in the Basic Law. While the Chief Executive is vested with extensive powers under the Basic Law, he is also subject to extensive checks and balances in the exercise of his powers that were hitherto not in existence in the previous colonial regime. For instance, while the Chief Executive may refuse to give assent to any bill if he considers that the bill is not compatible with the overall interests of Hong Kong and may return the bill to the Legislative Council for reconsideration, his option is limited if the Legislature returns the bill on reconsideration by no less than a two-third majority. He has either to give his assent or to dissolve the Legislature, a power that he could exercise only once during his term. If he decides to dissolve the Legislative Council and if the new Legislative Council passes the bill again by a two-third majority, the Chief Executive has to resign if he still refuses to assent to the bill. Besides, the Legislative Council is vested with the power to impeach the Chief Executive for a serious breach of law or a dereliction of duty, which power does not exist in the previous system. This has led many observers to conclude that the system under the Basic Law is one of checks and balances, whether it is executive-led or not. This debate is particularly intense in the development of representative government in Hong Kong. ${ }^{59}$

The courts have on a number of occasions expressed its view on the nature of the governance system, and have unambiguously come down in favour of a system of separation of powers. ${ }^{60}$ There are a number of implications of this view. It reinforces the principle of legality so that the executive Government is subject to law and, a fortiori, judicial review of executive action. It also means that the power of interpretation of law is vested in the judiciary. This includes the Basic Law, which provides that no laws in the HKSAR shall contravene the Basic Law. Accordingly, in the first case on the Basic Law, the Court of Final Appeal held that the power to determine whether any executive act or legislative provision contravenes the Basic Law and to strike down any incompatible legislative provision is vested in the courts. ${ }^{61}$ Thus, in one brush the Court of Final Appeal assumed the power of constitutional review and the power to strike down legislative acts that are inconsistent with the Basic Law when nowhere in the Basic Law expressly confers this power on the judiciary - a power which has been controversial in other jurisdictions. Secondly, it influences the development of the doctrine of margin of appreciation in that there are distinct constitutional roles and areas of competence for each of the three branches of Government so that the courts should afford deference to the other two branches of Government in exercising its powers of constitutional scrutiny. We will come back to this point in the next section.

${ }^{59}$ For a summary of the debates, see Benny Tai, "The Chief Executive", in J Chan \& C L Lim (eds), Law of the Hong Kong Constitution (Sweet \& Maxwell, $2^{\text {nd }}$ ed, 2015), Ch 7, at paras 7.013-7.021.

60 Leung Kwok Hung v President of Legislative Council of the HKSAR, HCAL 87/2006; Raza v Chief Executive of the HKSAR [2008] 3 HKLRD 561; Society for the Protection of the Harbour v Chief Executive in Council (No 2) [2004] 2 HKLRD 902.

${ }^{61} \mathrm{Ng} \mathrm{Ka}$ Ling v Director of Immigration (1999) 2 HKCFAR 4. 
Thirdly, the courts would be reluctant to interfere with the internal operation of the Legislative Council. There were a number of occasions where the exercise of powers of the Legislative Council was challenged, not only by members of the public, but also by members of the Legislative Council. In Chim Pui Chung v President of Legislative Council, ${ }^{62}$ a legislator who was convicted and sentenced to 3 years' imprisonment, challenged the order of the President of the Legislative Council to put on the agenda a motion to disqualify him under art $79(6)$ of the Basic Law on the ground that "conviction" and "sentence" under Art 79(6) referred to a final order of conviction and sentence after the appeal has been exhausted. The application was refused without entering into the question of jurisdiction. In Leung Kwok Hung $v$ Clerk to the Legislative Council, ${ }^{63}$ the applicant, who was newly elected to the Legislative Council, applied for a declaration that he was free to devise his own form of oath of office so long as the essence of the original oath was retained. His application for leave was refused on the ground that the legislation did not permit a departure from the statutory language of the oath without again entering into the question of jurisdiction. In another case of Leung Kwok Hung v President of the Legislative Council,64 the applicant challenged the ruling of the President of the Legislative Council to disallow him to move an amendment on the basis that it has the object or effect of disposing of or charging part of the revenue. He invited the court to grant a declaration that the relevant Rule of the Legislative Council contravened Art 73(1) of the Basic Law. The application failed on the ground that the remedy was not reasonably arguable. It was noteworthy that the court was not invited to intervene in any internal procedure of the Legislative Council or to pronounce on the legality of the decision of the President. Hartmann J sounded the caution that while the court has jurisdiction to intervene, this jurisdiction, having regard to the doctrine of separation of powers and the sovereignty of the Legislative Council under the Basic Law, should only be exercised in a restrictive manner. ${ }^{65}$

In Cheng Kar Shun v Li Fung Ying, 66 the applicant, who was a major real estate developer, challenged the power of a committee of the Legislative Council to summons witness in an investigation under art 73(10) of the Basic Law. It was argued that this power could only be exercised by the Legislative Council and not by one of its committees. For the first time, leave to apply for judicial review of the practice of the Legislative Council was granted. It is significant that the court was invited to intervene in an on-going proceeding of the Legislative Council. The application was ultimately dismissed on ground of statutory interpretation. The question of jurisdiction was not argued.

Finally, in a further case of Leung Kwok Hung $v$ President of Legislative Council, ${ }^{67}$ also known as the filibustering case, the Court of Final Appeal set out clearly the relationship between the courts and the Legislative Council. In that

62 [1998] 2 HKLRD 552.

63 HCAL 112/2004.

64 [2007] 1 HKLRD 387.

65 Ibid, at 397, para 31.

66 [2011] 2 HKLRD 555.

67 (2014) 17 HKCFAR 689. 
case, the issue was the legality of the ruling of the President of Legislative Council to cut short and close a debate. Having regard to the doctrine of separation of powers, the court held that whether the President has the power to terminate a debate was a matter for the court, but whether the power was properly exercised would be a matter for the Legislative Council. In general, the court shall not intervene in the internal procedure of the Legislative Council. It is for the Legislative Council to decide how it would like to make and apply its own rules to deal with the problem of filibustering, and the courts, in a system of separation of powers, should respect the sovereignty of the Legislative Council in this regard.

The doctrine of separation of powers is not set out in the text of the Basic Law. It was even politically controversial whether this principle was embodied in the Basic Law. Nonetheless, it is clearly an invisible constitutional principle in operation that has guided or influenced the courts in all these cases.

\section{From Proportionality to Manifestly without Reasonable Foundation: Prevalence of Civil and Political Rights over Social and Economic Rights}

The doctrine of separation of powers is also seen to be in operation in the context of social and economic rights. Chapter 3 of the Basic Law is titled Fundamental Rights and Duties of the Residents, in which it sets out a list of fundamental rights. Among them include both civil and political rights as well as social and economic rights, culminated in the important Article 39 which provides that no restriction of rights and freedoms shall contravene the ICCPR and the ICESCR as applied to Hong Kong and implemented through the laws of HKSAR. This chapter is not exhaustive of all fundamental rights, as the right to fair trial and the right to jury trial are provided in the chapter dealing with the Judiciary, whereas the right to property is protected in the chapter on Economy. While there is nothing in the Basic Law to suggest that there is a hierarchy among different types of rights, the courts have, through a series of decisions on proportionality, reached a stage that not all rights are of equal status.

The starting point is that in a civil society, the courts will vigilantly protect fundamental rights and freedoms and vigorously scrutinize any restriction on them. Any restriction will have to satisfy the legality and the proportionality tests. The proportionality test embraces the twin facets that the restriction bears a rational relationship to and does not go beyond what is necessary to achieve the objectives to be pursued. In developing the proportionality test, the courts soon adopt and modify the concept of a margin of appreciation to domestic law. In its original conception, this notion legitimizes an international tribunal to defer to the States in determining whether restrictive measures are necessary on the ground that domestic institutions are in a much better and more informed position to evaluate particular local needs and conditions. Formulated in this way, the concept has no place in domestic law, as it is not open to a local judge to claim unfamiliarity with local needs and conditions. However, the concept was soon modified to justify a degree of deference to the Executive Government or Legislature in recognition of their 
expertise, information advantage or constitutional roles. Thus, in Lau Cheong $v$ $H K S A R$, the Court of Final Appeal held that whether mandatory life imprisonment replacing mandatory death sentence was a necessary and proportionate response to murder was a highly charged political decision which the court should defer to the Legislature. ${ }^{68}$ While the doctrine of deference is justified on the dual grounds of expertise/competence and constitutional roles, the court is less prepared to defer to the executive or the Legislature if the ground of deference is based on a mere lack of expertise. Thus, in Kwok Kay Kwong v Medical Council of Hong Kong, ${ }^{69}$ it was argued that the Courts should defer to the judgment and expertise of the Medical Council who was in a better position to determine what kind of restriction on professional advertising by doctors would be necessary. Yet the Court of Final Appeal was prepared to subject the justifications to a searching scrutiny and eventually overrode the judgment of the Medical Council primarily because the decision involved free speech.

In contrast, the Court readily extended the concept to social and economic rights by adopting a new standard of manifestly without reasonable foundations. It readily accepted that allocation of resources in the context of socio-economic policies was a matter for the executive government so that a less vigorous scrutiny would be justified. Thus, in Fok Chun-wa v Hospital Authority, ${ }^{70}$ the Court held that in the context of allocation of limited public funds, the Government should be left to decide whether to have any social welfare scheme, and if so, its extent and who should benefit thereunder. It was not for the court to find an alternative solution and the courts would intervene only if the impugned measure had clearly transgressed beyond the range of alternatives. In that case, the issue was whether a differential and higher fee for obstetric service for non-Hong Kong residents could be justified. The differential fee regime was introduced to discourage Mainland pregnant mothers from giving birth in Hong Kong, as such incidents, due to their sheer number, have caused considerable anxieties and strains in obstetric service and hospital resources for Hong Kong pregnant mothers. The Court of Final Appeal found that a distinction based on residence status was entirely within the spectrum of reasonableness and that the measure was not discriminatory, taking into account, among other things, the need to ensure the sustainability of providing subsidized health services and the entitlement to subsidized health service not being a fundamental right.

The idea that social and economic rights are not fundamental rights has been expressed in some earlier cases. In Chan Mei Yee v Director of Immigration, Hartmann J held that social and economic rights were promotional and aspirational in nature and hence the ICESCR did not create any legally enforceable obligations. ${ }^{71}$ This has attracted a rebuke from the Social,

68 (2002) 5 HKCFAR 415 at 447.

${ }^{69}$ [2008] 3 HKLRD 524.

70 (2012) 15 HKCFAR 409, paras 62-81.

${ }^{71}$ HCAL 77/1999, 13 July 2000. See also Chan To Foon v Director of Immigration [2001] 3 HKLRD 109, 131-134, and Mok Chi Hung v Director of Immigration [2001] 2 HKLRD 125, where a similar sentiment has been expressed. 
Economics and Cultural Committee in its concluding observation on the Initial Periodic Report on the HKSAR. The Committee, in unusually strong language, "regrets" such views, which were "based on a mistaken understanding of the legal obligations arising from the Covenant" and urged the Government not to repeat similar views in judicial proceedings. ${ }^{72}$ In reply, the Government stated that "we note the Committee's observation that the Covenant is not merely 'promotional' or 'aspirational' in nature and accept that it creates binding obligations at the international level."73

While the Government's reply was ambiguous as to its stance on social and economic rights at domestic level, it did refrain from arguing that social and economic rights are aspirational or promotional in nature in subsequent legal proceedings. Instead, it urged, and to a large extent successful, the courts to afford a wide margin of appreciation to the Government whenever social and economic rights were engaged. The courts responded by developing the concept of manifestly without reasonable foundation, and in so doing, drew a distinction between cases involving socio-economic policies and cases involving fundamental rights or core values. Thus, in Kong Yunming v Director of Social Welfare, the Court of Final Appeal laid down a three-tier test: ${ }^{74}$

"In some cases involving fundamental rights such as freedom of expression or freedom of peaceful assembly, or rights bearing on criminal liability such as the presumption of innocence, the Court has regarded the restriction as disproportionate unless it goes no further than necessary to achieve the legitimate objective in question. This is sometimes called the "minimal impairment" test.

Similarly, in discrimination cases, where the differentiating inroad is based on certain personal characteristics sometimes referred to as 'inherently suspected grounds' such as race, colour, sex or sexual orientation, the Court will subject the impugned measure to 'intense scrutiny', requiring weighty evidence that it goes no further than necessary to achieve the legitimate objective in question.

However, it would not usually be within the province of the courts to adjudicate on the merits or demerits of government socio-economic policies. Where the disputed measure involves implementation of the Government's socio-economic policy choices regarding the allocation of limited public funds without impinging upon fundamental rights, or involving possible discrimination on inherently suspect grounds, the Court has held that it has a duty to intervene only where the impugned measure is 'manifestly without reasonable justification'."

\footnotetext{
72 UN Doc E/C.12/1/Add 58, paras 16, 27 (11 May 2011).

$732^{\text {nd }}$ Periodic Report of the HKSAR Government, paras 2.11-2.12, available at http://www.cmab.gov.hk/en/issues/culturalrights report.htm.
}

74 (2013) 16 HKCFAR 950, para 40. 
In short, a less vigorous scrutiny will be adopted in assessing the proportionality of any measures restricting social and economic rights because "the art 36 right to social welfare is not a fundamental right but a right which intrinsically involves the Government setting rules determining eligibility and benefit levels."75 In so doing, the courts equated social and economic rights with socio-economic policies and reinforced the second-class nature of social and economic rights. This approach is largely influenced by the courts' perception of separation of powers, namely that allocation of resources in socio-economic policies falls within the domain of executive prerogatives.

Notwithstanding its rhetoric on social and economic rights, the Court of Final Appeal in Kong Yunming did, to the surprise of many observers, adopt a rather vigorous scrutiny of the restriction on the right to social welfare and reversed unanimously the decisions of the lower courts. In that case, the issue was whether an extension of the eligibility residence requirement from 1 year to 7 years for comprehensive social welfare assistance was a violation of the right to social welfare under Art 36 of the Basic Law. The Government relied on the familiar argument that the extension was necessary to ensure the sustainability of the social welfare system. The Court, however, subjected this argument to vigorous examination of evidence. It found that the restriction was inconsistent with the family reunion policy and the population policy, that the extension was illogical as young children was exempted but not their parents, resulting in children without parental care or young children having to share their welfare assistance with their parents. It also found that the seven-year residence requirement was in fact targeted at the new arrivals from the Mainland, and the Government failed to substantiate the claim of sustainability when only $12-15 \%$ of the expense was attributable to the new arrivals. The Court examined closely the Government's budget, the breakdown of the expenditure on CSSA as revealed in the Legislative Council paper, various statistics and reports provided by the Government, and concluded that there was no rational connection between the justification of sustainability of the welfare system and the 7-year residence requirement, and that the 7-year residence requirement was a restriction on the Applicant's right to social welfare that was manifestly without reasonable foundation.

The approach of the court was exemplary of a vigorous scrutiny of restriction on a fundamental right. It casts doubt on any real difference between the minimal impairment test and the manifestly without reasonable foundation test, which, on its face, is reminiscent of the more conservative Wednesbury unreasonableness test in the common law. ${ }^{76}$ To that extent it is a welcome

\footnotetext{
75 Ibid.

76 Ip criticized that the manifestly without reasonable foundations test conservative and flawed: see Eric Ip, "Manifest Unreasonableness: The Doctrinal Future of Constitutional Review of Welfare Policy in Hong Kong" (2014) 44 HKLJ 55. While this criticism is valid on its face, the way the test was applied, at least in the case of Kong Yunming, is far from conservative. Indeed, others criticized the court for being too invasive: Po Jen Yap and Thomas Wong, "Public Welfare
} 
development. On the other hand, it would be too early to conclude that this case marks the dawn of a new era for social and economic rights and that the court is prepared to acknowledge social and economic rights as a fundamental right that is on par with civil and political rights. The Court itself was cautious in pointing out that the right to social welfare was not a fundamental right, that it was dealing with a scheme to provide "safety net needs", and that its decision may not apply to other forms of social welfare. ${ }^{77}$ Its approach may well be conditioned by the special facts in that case. ${ }^{78}$

Indeed, shortly after, the Court seems to have resorted once again to the inferior nature of social and economic rights. In the more recent case of $G A v$ Director of Immigration, the issue was whether the applicants, who were screened-in torture claimant and mandated refugees, were entitled to work when they have been in Hong Kong for 10-13 years and when there was no reasonable prospect of their resettlement in a foreign country. ${ }^{79}$ The Court of Final Appeal held that they could not rely on either the ICCPR or the Bill of Rights because of an effective reservation on immigration decisions. Insofar as the right to work in Art 6 of the ICESCR is concerned, the Government accepted that while there was no general domestic law that has given effect to the ICESCR, Art 6 has been implemented in domestic law through various provisions in the Basic Law and provisions in over 50 ordinances. Notwithstanding this concession, the Court held that there was no general, unrestricted right to work. The most that can be said is that "there is some allowance made for persons like the Applicants to be permitted to work, but this is far from the general, unrestricted right which is said to exist." 80 This is a regrettably narrow view of the right to work. In the first place, the right to work may be regarded as a right to freely enter into a contract of employment, which is well recognized in the common law. Secondly, a right to work does not mean an absolute right to work. It is subject to restrictions that are necessary and proportionate. Framed in this way, the issue would then be whether the restrictions imposed by the Director of Immigration not to allow the applicants to work were proportionate. This would allow the court to examine the substance of the issue and balance the competing considerations. Unfortunately, by rejecting that there is a right to work, the court found it even unnecessary to consider whether the Director of Immigration should exercise his discretion in a manner consistent with treaty obligations under the ICESCR on the basis that the ICESCR was not incorporated into

and the Judicial Over-Enforcement of Socio-Economic Rights in Hong Kong" (2014) 44 HKLJ 41.

77 At paras 23 and 138. See also para 40.

78 In the course of argument, the Court was apparently concerned that the case dealt with a scheme to provide safety net basic needs. There were also extensive documentations and evidence on the One-Way Permit System and the Population Policies, and the absence of consideration of any other length of residence requirement such that the 7-year residence requirement was obviously targeted at new arrivals from the Mainland.

79 (2014) 17 HKCFAR 27.

80 Ibid, at para 60. 
domestic law - a reminiscence that the ICESCR is aspirational and promotional in nature!

The upshot of this line of cases reveals an increasingly restrictive stance towards the rights of aliens. It has first been held that illegal immigrants from the Mainland had no legitimate expectation to a right to fair hearing and that the Director of Immigration had no duty to consider humanitarian grounds. ${ }^{81}$ It was then held that there was no discrimination to subject an alien mother from the Mainland to a differential and higher fee for public health service. ${ }^{82}$ In another case it upheld the constitutionality of a provision in the Immigration Ordinance that denied foreign domestic helpers ordinary residence in Hong Kong no matter how long they have stayed in Hong Kong. ${ }^{83}$ Then it was held that there was no right to work for mandated refugees or screened-in torture claimants even when they had stayed in Hong Kong for over 12 years with no reasonable prospect of resettlement in another country. ${ }^{84}$

Do these cases foreshadow a reversal of the liberal trend towards treatment of fundamental rights? The original conception of separation of powers that the Government is abide by law has gradually given way to another conception of separation of powers that the courts should defer to the Legislature or the Executive Government when it involves the constitutional competence of another branch of government. This is witnessed by the adoption of the manifestly without reasonable foundation test even in civil and political rights. In Kwok Cheuk Kin v Secretary for Constitutional and Mainland Affairs, ${ }^{85}$ the Court of Appeal re-interpreted the three-tier test adopted in Kong Yunming. In that case, the issue was whether a prohibition against a legislator who has resigned from the Legislature from taking part in the by-election for the vacant seat that was created by his resignation was a proportionate restriction on the right to vote. The restriction was a response to the attempt of some Legislators who tried to seek popular mandate and force an effective referendum on a controversial issue by resignation and then taking part in the by-election on a single-issue platform. While the right to stand for election is no doubt a civil and political right, the Court of Appeal held that:

"Properly read, in Kong Yunming, Ribeiro PJ applied the proportionality test and he was only referring to the difference in the intensity and standard of review in the application of the third limb of that test (proportionate restriction)." (para 28)

By reinterpreting the test in Kong Yunming, the Court of Appeal held that there was only one proportionality test and there was no separate minimal impairment test, thereby eschewing the difference between civil and political

\footnotetext{
${ }^{81}$ Ho Ming Sai v Director of Immigration [1994] 1 HKLR 21; Hau Ho Tak v Director of Immigration [1994] 2 HKLRD 202.

${ }^{82}$ Fok Chun-wa v Hospital Authority (2012) 15 HKCFAR 628.

${ }^{83}$ Vallejos $v$ Commissioner of Registration (2013) 16 HKCFAR 45.

${ }^{84}$ GA v Director of Immigration (2014) 17HKCFAR 27.

85 [2015] 5 HKLRD 881
} 
rights and social and economic rights. It maintained the test of manifestly without reasonable foundations for social and economic rights, but then decided to adopt the same test, or at least a wide margin of appreciation in favour of the Government, for the right to stand for election on the ground that the issue was political in nature. The application for judicial review failed. ${ }^{86}$

The reluctance of the courts to intervene in the allocation of public resources has long been recognized in the common law and could be traced back to the doctrine of separation of powers. This attitude manifested itself in the treatment of social and economic rights in the Basic Law, when the Basic Law itself has not drawn any such distinction. It has led the courts to develop a different notion of proportionality test, namely a test of manifestly without reasonable foundations, and the test was then extended even to the right to stand for election on the ground that the issue was political. The doctrine of separation of powers is not explicit, but it is certainly in operation.

\section{Conclusion}

Hong Kong is not an independent state. Under the One Country, Two Systems model, it has to operate within a country that has adopted a fundamentally different legal, social and political system. It is a precarious model that rests heavily on the goodwill of the PRC. At the time of the Joint Declaration, Hong Kong was already a modern metropolis with great economic success, and was responsible for almost $90 \%$ of foreign incomes of the PRC. Thirty years later, China has emerged as the second largest economic power in the world, with Hong Kong responsible for only less than 3\% of its GDP. Yet economic progress in the Mainland is not matched by its development of the rule of law, which still flourishes in Hong Kong. Over the years, Hong Kong has been subject to increasing social, economic and political influences from the Mainland. The rule of law, which embodies the independence of the judiciary, is probably the only aspect that distinguishes the two systems now. Thus, it is not surprising that the courts are trying very hard to preserve the integrity of the common law system and in particular, the objective and perceived independence of the judiciary, but at the same time, carefully restrain the exercise of their power.

In preserving the integrity of the common law system, the courts also try to preserve the previous systems, be it the health system, the education system, regulations of civil service, or the social welfare system. The promise of One Country, Two Systems is to last for at least 50 years. This promise could only be realized if the essence of the previous system is preserved. At the same time, the courts have to ensure that this would not fossilize the previous systems and allow them to evolve with changing social and economic conditions.

86 The Court of Appeal has refused to grant leave to appeal to the Court of Final Appeal. The applicant is currently applying for leave to appeal from the Court of Final Appeal. 
A challenging issue for the courts is the changing relationship of the three branches of government. The rule of law mandates the subjection of Government acts to the principle of legality. At the same time, the power of constitutional review, which the Court of Final Appeal managed to claim, requires the court to respect the sovereignty of the two other branches of government. In this sense, the doctrine of separation of powers goes hand in hand with the power of constitutional review. The influences of the doctrine of separation of powers under this new regime of constitutional review could be seen, not only in delineating the relations between the judiciary and the Legislature in judicial review of the functioning of the Legislative Council, but also in the deference to the Government and the Legislature in reviewing restrictions of social and economic rights.

None of these principles can be found explicitly in the text of the Basic Law. Yet it is also clear that they have been in operation and in influencing judicial decisions. Whether they are just distinct constitutional principles or fixed stars that punctuate in the night sky that could form a pattern of constitutional constellation remains to be seen. ${ }^{87}$ It is probably too early to find an invisible constitutional pattern behind the text in a constitution of barely 25 years old. Yet it is clear that there are at least some fundamental principles that lie behind the text. Preservation of the existing system is promised up to the year 2047. The system thereafter remains an open question at this stage, and will probably have to be decided at the latest in around the year 2030.88 In exploring the future in the not too distant future, there is a practical, if not also imperative, dimension for Hong Kong to identify any invisible constitutional fundamentals. This paper provides a modest attempt to do so.

${ }^{87}$ Lawrence Tribe, The Invisible Constitution (Oxford University Press, 2008), at p 72.

88 The negotiation on the future of Hong Kong was carried out in 1982, some 17 years before the changeover. This length of period is necessary for proper consultation and for the banking sector to operate on matters regarding finance and mortgages, which was a crucial factor that prompted the negotiation in the late 1970 s and the 1980 s. 